\title{
Interpretation of successful and failed events in entrepreneurial firms: Acknowledgement practice under uncertainty
}

International Small Business Journal: Researching Entrepreneurship 2022, Vol. 40(7) 845-874 (C) The Author(s) 2021

\section{(c) (i)}

Article reuse guidelines: sagepub.com/journals-permissions DOI: I0.|I77/026624262/I056303 journals.sagepub.com/home/isb

(SAGE

\section{David Johnson}

The University of Glasgow, UK

\section{Adam J Bock}

University of Wisconsin-Madison, USA

\section{Alex Thompson}

The University of Exeter, UK

\begin{abstract}
Event interpretation and acknowledgement drive behaviour and identity formation in organisations. Extant studies exploring this link have focused on large, stable organisations. We extend these studies to entrepreneurial contexts where individual behaviour and organisational identity are especially fluid. We analyse narratives of success and failure in entrepreneurial firms to identify and explore acknowledgement practice, which is the ad-hoc action (or inaction) of organisational actors and groups responding to observed events. We explore how uncertainty affects event interpretation and acknowledgement. Within entrepreneurial contexts, we show that event interpretation and acknowledgement biases influence responses to success and failure. The combination of these biases reveals four broad emergent organisational characteristics, which have important implications for organisational identity.
\end{abstract}

\section{Keywords}

event interpretation and acknowledgement, acknowledgement practice, uncertainty, emergent organisational characteristics, ritual, entrepreneurial firms 


\section{Introduction}

Functional, formalised mechanisms for interpreting, acknowledging and validating shared events have been studied as ceremony and ritual in large, established organisations (Dacin et al., 2010; Trice and Beyer, 1984). Within this context, celebrations, such as company parties (Rosen, 1988) and award-giving events (Anand and Watson, 2004), commend success and legitimise practice, often leading to expressions of happiness and joy. Expressions of loss, such as anger and commiseration, acknowledge failure (Bell and Taylor, 2011; Wolfe and Shepherd, 2015a). These responses by organisational actors to shared events determine what elements of practice and identity become embedded or deinstitutionalised (Gioia and Thomas, 1996; He and Brown, 2013).

Whilst the characteristics of event interpretation and acknowledgement in large, established institutions and organisations have been extensively studied through the enaction of ceremony and ritual (see Islam and Zyphur, 2009), we know little about how organisational actors, particularly founders of entrepreneurial firms, interpret and acknowledge events when uncertainty is high. This lack of knowledge is challenging; unlike large, stable organisations, individual responses to organisational events in uncertain entrepreneurial contexts disproportionately affect organisational characteristics and identity (Navis and Glynn, 2010). At the same time, because meaning-making is context-specific, event interpretation and acknowledgement are likely to emerge differently in entrepreneurial contexts. In particular, in entrepreneurial contexts, goals, priorities and actions are less clearly circumscribed, and improvisation is common or even expected (Baker et al., 2003; Ciuchta et al., 2021). Moreover, in entrepreneurial firms, behavioural norms are unformed and blurred by perceived environmental uncertainty (Milliken, 1987).

The research focus on large, stable organisational contexts presents a significant gap in our knowledge of organisational behaviour in entrepreneurial firms. We extend existing theory by asking whether our current understanding of the mechanisms of event interpretation and acknowledgement in large organisations, which present as organisational ceremony and ritual, hold true within entrepreneurial firms. More specifically, understanding how organisational actors, such as founders and managers, interpret and acknowledge successful and failed events in uncertain entrepreneurial contexts is important since this can assist our understanding of emergent organisational characteristics and, subsequently, organisational identity.

To date, there has been limited research on organisational identity within an entrepreneurial context (Morris et al., 2018), particularly the mechanisms relating to how entrepreneurs shape organisational identity (Snihur, 2016). To explore this gap, we narrowed our investigation to explore how interpretation and acknowledgement of organisational events drives organisational identity within entrepreneurial firms. In entrepreneurial firms, uncertainty is high and event interpretation and acknowledgement are less formal. The response to observed events and outcomes likely has a profound effect on the entrepreneurial organisation. At entrepreneurial firms, organisational identity is fluid and significantly affected by founders and managers. Individual responses to events and outcomes are closely tied to the entrepreneurial venture's identity (Domurath et al., 2020).

We examine how founders and managers in entrepreneurial firms interpret and acknowledge selfreported successful and failed events. To frame our study, we ask: 'In entrepreneurial firms, how does uncertainty impact event interpretation and acknowledgement?' Our findings reveal how founders and managers at entrepreneurial firms respond, or fail to respond, to observed events when uncertainty is high. We define this behavioural response as acknowledgement practice to distinguish it from event interpretation and acknowledgement in large organisations (Dacin et al., 2010; Isabella, 1990). Specifically, we reveal acknowledgement practices to have four distinctive characteristics, which differ from event interpretation and acknowledgement in large, stable 
organisations. In addition, utilising Milliken's (1987) framework for perceived environmental uncertainty, we show that uncertainty has a profound effect on event interpretation and outcomes within entrepreneurial firms. In particular, we reveal how uncertainty leads to both interpretation and acknowledgement biases, resulting in the manifestation of emergent organisational characteristics.

We make four contributions to organisational behaviour scholarship, extending recent research investigating entrepreneurial success and failure (Angel et al., 2018; Jenkins and McKelvie, 2016). In so doing, we provide a more nuanced view of how event interpretation and acknowledgement within entrepreneurial firms influences organisational identity (Domurath et al., 2020; Morris et al., 2018; Snihur, 2016). First, we distinguish between event interpretation and acknowledgement in entrepreneurial contexts from responses to event outcomes in large, stable organisations. Second, we reveal the impact of uncertainty on event interpretation and acknowledgement at entrepreneurial firms. Third, we identify biases that shape event interpretation and acknowledgement. Fourth, we propose that these biases generate emergent organisational characteristics, which has important implications for how individuals embed event outcomes and impressions into organisational identity. Our research opens new directions in organisational behaviour at entrepreneurial firms and emphasises the importance of developing meso-level theory specific to entrepreneurial contexts.

The remainder of this article proceeds as follows. First, we describe the theoretical framing underpinning our research. Second, we describe the methodological framework of the study. Third, we present descriptive findings of the observed phenomena based on narratives of success and failure at entrepreneurial firms. Fourth, we then describe the characteristics of acknowledgement practice at entrepreneurial firms, discuss the influence of uncertainty on event interpretation and acknowledgement and explore how interpretation and acknowledgement biases leads to emergent organisational characteristics. Finally, we conclude by considering the limitations of our study, which reveals important directions for future research.

\section{Theoretical framework}

We frame our study by considering the implications of uncertain entrepreneurial contexts on event interpretation and acknowledgement. First, we begin our theorising by exploring how event interpretation and acknowledgement is enacted and validated in large, stable organisations by reflecting upon the extant ceremony and ritual literature, which are key planned behavioural responses to event outcomes. Second, since event interpretation plays a critical role in organisational identity formation, we continue our discussion by exploring the organisational identity literature. Third, we conclude our theoretical framing by highlighting how uncertainty challenges our understanding of how organisational events are interpreted and acknowledged.

\section{Event interpretation and acknowledgement in established organisations: Ritual and ceremony}

Ceremonies and rituals acknowledge specific events, channelling cognitive content and behavioural activity toward the cultural expectations of organisations and their members (Smith and Stewart, 2011). At the most fundamental level, ceremony and ritual play a key role in the creation and transmission of meaning (Kulkarni, 2020). Ceremonies are elaborate, dramatic and planned activities, closely linked to ritualistic behaviour (Beyer and Trice, 1987). Similarly, rituals are public displays of social action whereby group values and identity are enacted (Islam and Zyphur, 2009). 
By definition, ritual enactment is a formal process, constituting a planned and official occasion (Di Domenico and Phillips, 2009). For example, annual office Christmas parties (Rosen, 1988), formal dining practices at historic universities (Dacin et al., 2010) and prestigious award ceremonies (Anand and Watson, 2004) emphasise the planned nature of event interpretation and acknowledgement. These activities signify the institutional- or organisational-wide visibility of such enactment, which typically focus on public events (Kulkarni, 2020). The role of ritual in communicating beliefs, values, success, failure and performance across groups and organisations is important. Formalised rituals manage work structure and align behaviours to organisational strategy (Van Den Ende and Van Marrewijk, 2018). The enactment of rituals across organisational communities influences organisational characteristics and outcomes (Johnson et al., 2010). In the context of sociodynamics, rituals, such as informal organisational gatherings or meetings, celebrate or commiserate organisational events through the exchange of information amongst actors, legitimising existing processes and acting as a conduit for building social relationships (Bell and Taylor, 2011; Rosen, 1988). Ritual informs and reinforces collective meaning-making, which is essential to coherent and effective decision-making and practice (Garreau et al., 2015).

Ceremony and ritual pervade both large and entrepreneurial organisations. However, in contrast to entrepreneurial firms, large organisations have more established formal routines and rituals, and more processes in place to cope with uncertainty (Islam and Zyphur, 2009; Smith and Stewart, 2011). In particular, within large organisational contexts, event interpretation and acknowledgement assimilate actors into institutionalised values and behaviours, which drive information exchange, social cohesion, identity, and image. At the same time, these micro-level activities influence both organisational continuity and higher-level institutional orders (Dacin et al., 2010). Surprisingly, despite the fact that more than $95 \%$ of all organisations have less than 100 employees (Statistics of US Businesses, 2018), scholars have focused their attention on investigating ceremony and ritual on the $5 \%$ of large organisations at the expense of entrepreneurial firms.

Firm success or failure often depends on the effective interpretation of uncertain information, processes and environments (McMullen and Shepherd, 2006). Whilst this is true for all firms, nowhere is this more evident than at entrepreneurial firms (Walsh and Cunningham, 2016). Unlike large, stable organisations, founders at entrepreneurial firms must navigate the complexities of the entrepreneurial process, often under high levels of uncertainty, which stems from scarce resources, age-based vulnerability and volatility, (Sarasvathy, 2001; Shane and Venkataraman, 2000; Stinchcombe, 1965). As these entrepreneurial founders navigate the entrepreneurial process, they make specific judgements and take action in an attempt to resolve uncertainty (Packard et al., 2017). Accordingly, in this fluid and fast-paced environment inherent to entrepreneurial firms, event interpretation and acknowledgement can have profound effects on organisational identity.

\section{From event interpretation and acknowledgement to organisational identity}

Both ceremony and ritual are important organisational functions that create and transmit meaning and identity at organisations (Brown, 2017; Turner, 1969). Rituals confer symbolic value to events and assist organisational members to make sense of who (or what) is successful and which developments are worth exploiting (Anand and Watson, 2004). The relationship between ritual and organisational identity is important (Brown, 2017; Corley and Gioia, 2004).

Rituals often convey important messages through narrative (Islam and Keliher, 2018; Weick, 1995). These narratives help organisational members to participate in a shared understanding of specific events (Boje, 1995; Mazmanian and Beckman, 2018). For example, one form of organisational storytelling generates a heroic narrative in which organisational actors overcome obstacles 
(Anderson and Warren, 2011). An alternative form of storytelling is externalising failure (Gabriel, 2000).

Ultimately, organisational actors embed event outcomes and meanings onto an evolving organisational narrative scaffold. The narratives and behaviours of organisational members thus shape organisational identity (Cornelissen et al., 2007). The nature, purpose and interpreted meaning of an organisation is constructed from the formal and informal conversations, gossip and dialogues amongst individual members (Mills, 2010). At times, narratives may conflict, and the narratives and behaviours of those in the most senior positions within the organisation may impart a greater influence on organisational identity. Since narratives and dialogues are open to interpretation and negotiation, identity is dynamic and fluid (Ernst and Schleiter, 2019; Gioia et al., 2000), especially in entrepreneurial firms. Because interpretation is inherent to identity formation, the links between ritual and identity are context specific (Johns, 2006). However, event interpretation and acknowledgement are blurred by perceived environmental uncertainty (Milliken, 1987).

Event interpretation and acknowledgement in established organisations interacts with organisational identity (Dutton and Dukerich, 1991). Our understanding of event-specific responses under uncertainty within entrepreneurial contexts, and how this subsequently influences organisational identity remains fuzzy and warrants further investigation (Ashforth, 2020).

\section{Event interpretation and acknowledgement under uncertainty}

Uncertain environments have important implications for individual and team behaviours and organisational processes (Gilson and Davis, 2019). The entrepreneurial process, which consists of the identification and exploitation of opportunities and associated outcomes (e.g. success or failure), is fraught with high uncertainty (Rauch et al., 2018; Shane and Venkataraman, 2000; Townsend et al., 2018), which fluctuates along the different stages of the entrepreneurial process (Packard et al., 2017). For example, earlier-stage entrepreneurial firms exploiting opportunities face higher levels of uncertainty since they face liability of newness, scarce resources, a lack of routines and procedures and established identity (Stinchcombe, 1965; Yang and Aldrich, 2017).

Environmental uncertainty is central to understanding how entrepreneurial firms manage resources, organise structures and make choices (McMullen and Shepherd, 2006; Sirmon et al., 2007). Entrepreneurial firms must respond to uncertainties while establishing a venture identity. Within this fast-paced environment, event interpretation and acknowledgement may not be public or even possible. As such, responses to events become less visible to the entire organisation, which may prevent organisational-wide communication of important information. In entrepreneurial firms, this sequence of activities can have a profound effect on venture identity.

Venture success depends on individuals recognising and responding to uncertainties (McMullen and Shepherd, 2006). At entrepreneurial firms, small decisions can lead to significantly greater organisational change than at large organisations (Barr et al., 1992). Since entrepreneurial organisations are defined as being resource-constrained (Baker and Nelson, 2005), rituals are likely to be informal. For example, these organisations may not have formal or traditional rituals and routines, such as office parties, systemised rewards systems or 'employee-of-the-month' certificates to acknowledge event outcomes. Therefore, within entrepreneurial contexts, event interpretation and acknowledgement practices are less likely to be planned and publicly demonstrated. Instead, such interpretive practices are likely to be ad-hoc, much more informal and represented by the immediate or near-term interpretation and acknowledgement of the observed, discrete circumstances.

Generally speaking, celebrating success is easy; acknowledging and learning from failure is difficult. Understanding how entrepreneurs and firms respond to failure is of particular interest 
(Jenkins and McKelvie, 2016, 2017; Walsh and Cunningham, 2016). Event failure is a crucial consideration for firms of all sizes but is particularly inherent to the entrepreneurial process (Hunter et al., 2021; Jenkins and McKelvie, 2017). Unsurprisingly, however, scholars have made limited progress exploring failure in entrepreneurial contexts (Yamakawa et al., 2015).

Prior research has demonstrated both endogenous and exogenous biases towards responses to failure (Eggers and Song, 2015; Mantere et al., 2013; Rogoff et al., 2004). At the same time, studies have revealed failure responses to differ both amongst entrepreneurs (Mandl et al., 2016) and between entrepreneurs and non-entrepreneurs (Zacharakis et al., 1999). In other research, responses to failure have been illustrated to be de-emphasised (Stevenson and Jarillo, 1990), as well as evidence of motivating from failure (Cardon and McGrath, 1999). Failure rationalisation processes rationalise or externalise negative events (Caldwell and O'Reilly, 1982).

Interpretation and acknowledgement provide the opportunity for entrepreneurs to make sense of failure which in turn, affords the opportunity to learn from failure (Walsh and Cunningham, 2016). Stories of failure have become recognised as important emotional and sense-making devices (Byrne and Shepherd, 2015; Mantere et al., 2013; Wolfe and Shepherd, 2015b). Research has shown that organisations benefit from absorptive capacity in learning from failure (Meschi and Métais, 2015) but entrepreneurial firms, by definition, have limited absorptive capacity while exploiting novel opportunities. Learning from failure has potentially important consequences for subsequent firm regeneration and success (Cope, 2011; Habersang et al., 2019; Walsh and Cunningham, 2017). Recognising that responses to success occur both at the organisation- and individual-level, a key gap in the literature is a micro-level description of the mechanisms that organisational actors, particularly founders, utilise to interpret events, including failure, and convert such interpretations into acknowledgement and response behaviours (Walsh and Cunningham, 2017).

We focus our study on how founders and managers, within entrepreneurial firms, interpret and acknowledge events and outcomes under uncertainty. In particular, we reveal that acknowledgement practice is the ad-hoc behavioural response to event interpretation where uncertainty, lack of resources or lack of precedence precludes ritual or ceremony. Specifically, we focus on entrepreneurial firms actively exploiting new opportunities, where judgement-based behaviour under uncertainty is widespread (McMullen and Shepherd, 2006) and market position and resource configurations are not fully formed (Katila et al., 2012). To explore the role of uncertainty on event interpretation and acknowledgement, we rely on the use of Milliken's (1987) framework for perceived environmental uncertainty.

\section{Methods}

\section{Data}

We focused on event interpretation and acknowledgement at entrepreneurial firms, as reflected in founders and managers narratives of a successful and failed event. We utilised a theoretical sampling approach (Charmaz, 2006). Entrepreneurs and entrepreneurial organisations were identified via the researchers' personal contacts and professional networks. Specifically, these entrepreneurial firms were exploiting new/developing opportunities from weak market and resource positions, and included organisations that had few employees other than the founder(s). At the same time, these entrepreneurial firms were operating in fast-paced and uncertain markets. For one of the entrepreneurial firms in our dataset, the founder offered us access to members of his executive and senior management team, which we opportunistically acted on. Our firm selection included informants from firms based in the United States (US) and United Kingdom (UK). The firms spanned a variety 
Table I. Study informant and firm information.

\begin{tabular}{llllll}
\hline Firm & Industry & Geography & Approx. Firm FTE & Informant & Informant role \\
\hline 1 & Online music services & US & $10-24$ & 1 & Founder, CEO \\
2 & Health care & UK & $<10$ & 2 & Founder, CEO \\
3 & Packaging & UK & $<10$ & 3 & Founder, CEO \\
4 & Network services & US & $51-99$ & 4 & Founder, president \\
& & & 5 & VP \\
5 & Online services & US & $100-250$ & 6 & VP \\
& & & 7 & CEO \\
6 & Consulting & UK & $<10$ & 8 & Founder, CSO \\
7 & Imaging hardware & UK & $<10$ & 9 & Founder, CEO \\
8 & Consumables & UK & $10-24$ & 10 & Founder, CEO \\
9 & Online travel & US & $<10$ & 11 & Founder \\
10 & Materials & US & $<10$ & 12 & CEO \\
11 & Online training & UK & $<10$ & 13 & Founder, CEO \\
12 & Human resources & UK & $<10$ & 14 & Founder, CEO \\
13 & Edutainment software & UK & $<10$ & 15 & Founder, CEO \\
14 & Manufacturing & UK & $<10$ & 16 & Founder, CEO \\
15 & Online financial services & UK & $10-24$ & 17 & Founder, CEO \\
16 & Mobile networking & UK & $<10$ & 18 & Founder, CEO \\
17 & Edutainment & UK & $<10$ & 19 & Founder, CEO \\
18 & Online services & US & $100-250$ & 20 & Founder, CEO \\
& & & 21 & Founder, president \\
& & & 22 & CFO \\
& & & 23 & VP \\
& & & 24 & VP \\
& & & & Senior manager \\
& & & & Senior manager \\
& & & & Senior manager \\
\hline & & & &
\end{tabular}

a Unless otherwise noted, full-time equivalent is at time of interview.

of industries and business models, including pharmaceuticals, general manufacturing, IT and service businesses (Table 1). Firm and informant information is shown in Table 1.

A total of 27 interviews were conducted at 18 organisations. At 14 of the 18 organisations, we interviewed the founder only. At another 2 of the 18 organisations, we interviewed the founder and senior level executives. At the remaining 2 of the 18 organisations, we interviewed the CEO, along with a senior level executive at one of these organisations. In all instances, interviewees had significant responsibility for the organisation's strategic direction. Twelve of the organisations had fewer than 10 full-time equivalents; three had less than 25 full-time equivalents; and three between 50-250 full-time equivalents. Our decision to focus on founders, CEOs and senior executives and managers was based on the rationale that these groups of informants were ultimately responsible for: (1) the exploitation of opportunities within the firms; (2) the management of resources to exploit such opportunities; and (3) firm-level decision-making and strategy.

Informants were asked to describe an organisational event that they perceived to be a success and an organisational event that they perceived to be a failure. We explicitly sought to avoid bias by asking participants to identify successes and failures, rather than categorising them ourselves. Specifically, we were less concerned about whether a given event was, factually, a success or failure. 
Instead, we were interested in whether it was interpreted, and responded to as such, by organisational participants. This is, after all, a critical aspect of perceived environmental uncertainty, where organisational actors are fundamentally uncertain about the nature and interpretation of events. Normally, post-hoc rationalisation and sense-making effects would be potential challenges to data integrity. Our study, however, examines how organisational participants embed their interpretations, including post-hoc rationalisation and sense-making, into organisational identity. We also mitigated risks of misinformation by requiring participants to recount recent successes and failures for which they had direct involvement or oversight.

One complete story, each of success and failure, were collected from informants. Throughout the data collection process, respondents were given freedom to direct flow and topic(s), with little or no direction from the interviewer beyond the initial request for the narratives. In a minority of cases, the interviewer prompted the informant to disclose additional information about acknowledgement of success or failure in accordance with long interview practices (McCracken, 1988). This approach facilitated active and reflective meaning-making (Bauer, 1996). We recognise individual differences towards interpretation and acknowledgement of success and failure (Mandl et al., 2016; Packard et al., 2017; Zacharakis et al., 1999). For example, a founder may interpret and acknowledge an event as a success, yet a manager in the same firm may interpret and acknowledge the same event as a failure. Our study sought to reveal how founders and managers interpret and acknowledge selfreported successful and failed events.

The length of the interviews ranged from $25 \mathrm{~min}$ to $60 \mathrm{~min}$. The study dataset includes 54 narratives extracted from the interviews: 27 narratives of success and 27 narratives of failure. Field notes were generated during and immediately after each interview for reference.

\section{Procedures for data analysis}

We utilised an exploratory, inductive analysis (Charmaz, 2006) to identify aspects of behaviour associated with event interpretation and acknowledgement. Our analysis was informed by grounded theory-building (Straus and Corbin, 1990). To extract themes and examples from the data, we reviewed the audio files, field notes and transcripts of the interviews. We employed inductive analysis to allow themes to emerge from the data (Spiggle, 1994), as well as account for the relationships and properties of observed processes and mechanisms (Dey, 2007).

Although we relied primarily on open coding, we triangulated the coding with the higher-level constructs and themes embedded in the narratives (Strauss and Corbin, 1990). We employed the constant comparative method (Glaser, 1965) to reflect on observations and conclusions. This required fluidly shifting between data, coding and constructs to elicit the robust relationships between categories (Charmaz, 2006). The resulting structures were compared for similarities and distinctions on an iterative basis to confirm construct validity and interpretations. Since coding involves reductionism, we were cautious not to lose sight of the intent and 'sense' of the intact narratives. We often coded our data across units of analysis to preserve narrative structure and tone (Glaser, 2001).

Theoretical sensitivity is an essential component of theory-building during inductive research (Glaser, 2001). We engaged in regular discussions to further winnow and focus the data structure, and to reveal implicit assumptions and possible sources of interpretive bias. We took regular inventory of our data to review and summarise emerging themes. An online wiki was utilised to track proposed changes between meetings. Our process reflects a constructivist interpretation of organisational experience. It is important to note that lack of response is also a type of acknowledgement practice. The data structure developed from our data analysis procedures is shown in Table 2. 
Table 2. Data structure.

\begin{tabular}{|c|c|c|}
\hline First order codes & $\begin{array}{l}\text { Second order } \\
\text { categories }\end{array}$ & $\begin{array}{l}\text { Theoretical } \\
\text { dimensions }\end{array}$ \\
\hline $\begin{array}{l}\text { Single responses - not repeated } \\
\text { Over reliance on e-mail for rapid acknowledgement } \\
\text { Single organisational actor (typically founder) solely } \\
\text { responsible for response } \\
\text { No planning involved in acknowledgement response } \\
\text { Improvised reactions }\end{array}$ & $\begin{array}{l}\text { Ad-hoc reactions } \\
\text { Immediate reactions } \\
\text { Individualistic } \\
\text { Informal practices }\end{array}$ & $\begin{array}{l}\text { Acknowledgement } \\
\text { practices at } \\
\text { entrepreneurial } \\
\text { firms }\end{array}$ \\
\hline $\begin{array}{l}\text { Challenges surrounding assessment and interpretation of } \\
\text { events } \\
\text { Adjusting goals to meet event outcomes due to limited } \\
\text { information and/or resource scarcity } \\
\text { Ambiguity surrounding how other organisational actors } \\
\text { respond }\end{array}$ & $\begin{array}{l}\text { Event-effect } \\
\text { State } \\
\text { Response }\end{array}$ & $\begin{array}{l}\text { Perceived } \\
\text { environmental } \\
\text { uncertainty }\end{array}$ \\
\hline $\begin{array}{l}\text { Failure rationalisation } \\
\text { - Failure as "learning" } \\
\text { - Failure as "necessary" } \\
\text { - Failure as "problem-solving" } \\
\text { - Failure as experimentation } \\
\text { - Unavoidable failure } \\
\text { Success rationalisation } \\
\text { - Success as "necessary to survival" and not worthy of } \\
\text { celebration } \\
\text { - Success as reason to raise the bar, move on } \\
\text { Externalisation of event outcome cause }\end{array}$ & $\begin{array}{l}\text { Rationalisation } \\
\text { Event re-interpretation } \\
\text { Event blurring }\end{array}$ & Interpretation bias \\
\hline $\begin{array}{l}\text { Inhibited response } \\
\text { Inhibited mourning } \\
\text { De-emphasis of failure } \\
\text { De-emphasis of success } \\
\text { Muted celebration } \\
\text { Inflated significance of event outcomes } \\
\text { Exaggerated celebration } \\
\text { Motivating from failure }\end{array}$ & $\begin{array}{l}\text { Acknowledgement } \\
\text { inhibition } \\
\text { Exaggerated } \\
\text { acknowledgement }\end{array}$ & $\begin{array}{l}\text { Acknowledgement } \\
\text { bias }\end{array}$ \\
\hline
\end{tabular}

More specifically, at the start of the analytical process, we independently open-coded first order observations across the dataset. During this process, we repeatedly observed event interpretation and acknowledgement portrayed as being 'single responses - not repeated', initiated by a 'single organisational actor' (i.e. founder), in which there was 'no planning involved', and where event interpretation and acknowledgement relied upon 'improvised reactions'. In addition, our transcripts illustrated the 'challenges surrounding assessment and interpretation of events', which required founders and managers to 'adjust goals to meet event outcomes' and resulted in 'ambiguity surrounding how other organisational actors respond'. As a result of these challenges and uncertainties, the interview transcripts revealed how founders and managers were, subsequently, engaging in 'failure and success rationalisation'. At the same time, the transcripts also showed how founders and managers display an 'inhibited response' to events whereby they 'inhibit mourning' or demonstrate a 'de-emphasis of failure or success'. We also observed an 'inflated significance of events', whereby founders and managers reveal 'exaggerated celebration' or 'motivating from failure'. 
Following this first-order coding, we then compared coding trees and interpretations, generating a structure of second order categories. In doing so, we arrived at four broad themes, with one theme being guided by the uncertainty literature (see Milliken, 1987). The first theme illustrated the 'adhoc', 'immediate', 'individualistic' and 'informal' nature of event interpretation and acknowledgement. The second emphasised the different dimensions of uncertainty - 'event-effect', 'state' and 'response' - and was guided by Milliken's (1987) uncertainty framework. In particular, state uncertainty refers to a lack of clarity on the venture's current status. The inability of individuals to predict the impact of environmental changes on the firm is referred to as effect uncertainty. Finally, response uncertainty reflects the difficulties in foreseeing the consequences of a response choice (Milliken, 1987). The third theme comprised of 'rationalisation' and 'event re-interpretation and blurring'. Finally, the fourth theme illustrated both the 'inhibited' and 'exaggerated' nature of acknowledgement.

This second order categorising organised our observations and established a preliminary interpretation of cognitive and behavioural processes, leading to four overarching theoretical dimensions (Coffey and Atkinson, 1996; Gioia et al., 2012). Specifically, these theoretical dimensions reveal 'acknowledgement practices at entrepreneurial firms' and how 'perceived environmental uncertainty' leads to 'interpretation bias' and 'acknowledgement bias'.

\section{Findings}

Our findings reveal how, during high levels of perceived environmental uncertainty, founders and managers in entrepreneurial firms respond to successful and failed events via acknowledgement practices. We further reveal how this phenomenon leads to interpretation and acknowledgement biases. Table 3 highlights some examples of the types of self-reported successful and failed events discussed within our dataset.

\section{Perceived environmental uncertainty}

Our analysis reveals how uncertainty influences event interpretation and acknowledgement in entrepreneurial firms:

Event-effect uncertainty. We witnessed informants being challenged to clearly recognise and distinguish success and failure. Due to organisational goals, priorities and norms still being negotiated within the entrepreneurial firms under investigation, informants struggled to objectively assess events:

"It was very successful as he wanted to meet me, and the fact that he took time out of his busy schedule to meet me meant that I was onto something, and from that point of view, yes, that was the benefit... the experience wasn't particularly beneficial - there was nothing tangible - and I was a little bit deflated because you go in and you think it could be huge or it could be nothing, and unfortunately the actual tangible result was nothing. " [Informant \#14]

State uncertainty. Additionally, we observed a further hurdle to event interpretation stemming from unclear definitions of success or failure. In particular, in our dataset, informants had clear long-term goals for their entrepreneurial ventures, such as profitability, market share, exit value or various types of change agency. However, informants did not have clear near-term measures of success. Whilst the apparent goal was clear, and appropriate information was available to informants, these 
Table 3. Examples of self-reported successful and failed events.

Self-reported successful events

"Right, my success story of the year. There have been many successes but this one probably is the most significant for us going forward as a business. So, I was on the radio... with two million listeners and I had a three-minute innovation slot, and this was amazing... anyway it was great, and I got a lot of coverage and within, like, 30 min of being on there was about $\mathbf{3 0 0}$ hits on the Web site, it was really good..."

"So, Nov $10^{\text {th }}$ he comes up, it's an enjoyable week, we don't get much done and on the final night that he's here we're working through the night so that we can submit the app on Nov $17^{\text {th }}$ to the app store... I was like, 'we're in the app store!' 'you have to go download it now'... suddenly, we see loads of people signing up and l'm like, 'oh my god, what's gone on?' and realise that we've been posted on techcrunch!"

"We were successful in doing that, I mean, the success was that we started out to do a million and a half round of funding... we were over-subscribed, we wound up with a $\$ 2 \mathrm{M}$ round of funding. We were able to bring in two strategic investors, one of whom's a very large international company. We were able to bring in two funds and then partners from another fund, so we were able to get in some funds that could potentially bridge us and lead us into the next round, so that was important as well."

"But the real win was probably a few months ago when the number two Chinese provider agreed to take our product and incorporate it into their systems. And like a month after that the number four player in China decided to take it, which was huge. We were sitting here going, 'two out of the top four, this is great.' and we really got to the point where we realised that we might actually have a business here now to extend into the Chinese market."
Self-reported failed events

"Sort of sad that failure has come to my mind faster than successes! so, we've committed to the company in Jul of this year that we would have a profitable fourth quarter - we did not have a profitable fourth quarter, in fact we were far less profitable than we had even initially anticipated, so big failure."

"So, we acquired a lot of businesses... We bought a company and at some point, that grew big enough where we decided, 'okay, we'll have three divisions inside of our company... and over time it became pretty clear that the deliverability business is where the future was. So, I guess to a certain extent that was a mistake... when you're starting a business and stuff doesn't go the way you want it to, you just change what you're doing, you know, and that may require going out of business and starting another business, but it's all an experiment."

"Well, we finally got this launched... and it wasn't that long to develop, and it probably helped their development process on their end a little better because they didn't have much experience doing this. And we launched this a few weeks back and as of today, we haven't sold one! I mean, I just consider that a failure out of the gate... I mean, we should've started selling them day one, but when I look back, I say, 'well, did we tell anybody about it?' well, we told them about it 7 days after we launched, so it's buried in that column on our Web site - we haven't really marketed the product... so the failure was not the building of the product, the failure was there just wasn't a launch of the product and I'm somewhat humbled by it but ashamed too because if I know how to do one thing is market and sell music software."

"So, we bid for a piece of work for a very large, very well recognised company on a very large project... and we had a source that was very close to this company... the source wasn't at the company, but the source knew somebody at the company who was involved in the process, not in an underhand way, you couldn't influence the process, but just was aware and could give us more information. So, our chances of success were actually looking pretty good... anyway, we lost the whole of it... Snatched, I think it was $£ 580,000$, whatever, snatched from the jaws of victory." 
informants were unable to assess whether sufficient progress was being made in meeting the specific organisational goals:

"So, we really haven't acknowledged a failure because we haven't been at it long enough, but we have discussed it almost daily on how to get this thing going... I haven't checked the numbers today, but my guess is we've probably sold one or two pieces by now, but I was hoping one or two pieces a day, not in the first three weeks." [Informant \#1]

State uncertainty is also a function of limited information or processing capacity. We witnessed informants reflecting on the difficulties in accessing, processing and interpreting information required for reliable assessment of status.

Response uncertainty. Our findings also revealed informants at entrepreneurial firms who struggled with, or were unable to understand, how other actors at the organisation would respond to event interpretation and acknowledgement, which is reflected in response uncertainty. For example, in the excerpt below, we see a co-founder unsure of how his colleague would react to a looming deadline and respond to a failed product demonstration:

\begin{abstract}
"I just said to him, 'look, this needs to be done'... he knew I was panicking... he just sent me away and said, 'go and get a good night's sleep... I just need to do the work.' So, he stayed up the entire night doing it... but we turned up with this half-baked product... It was just awful. I walked away from that, and I was just so embarrassed... but [co-founder name] was just like, 'well, you know, whatever, it was okay!!!” [Informant \#15]
\end{abstract}

\title{
Acknowledgement practice
}

Ad-hoc reactions. Across our observations of event interpretations and acknowledgement, we witnessed responses that differed from event responses in large, stable organisations. More specifically, across our observations, acknowledgement practices of successful and failed events were one-time, ad-hoc reactions to specific events rather than repeated responses that we observe in large organisations.

Immediate reactions. In addition, we witnessed immediate responses to successful and failed events where little or no purposeful planning takes place. For example, informants consistently reported electronic communication as the primary mechanism for immediate, ad-hoc response behaviours for a variety of accomplishments and failures. These included minor instances, such as losing a small client, as well as significant events involving company survival, dramatic changes in strategic policy, venture financing events and wide-ranging decisions about products and customer interaction. Such organisational reliance on electronic communication de-personalises event interpretation and acknowledgement. In our dataset, electronic communication was commonly described as the obvious, and in numerous cases, the only mechanism for acknowledgement:

"Yeah, we regularly do that sort of thing. We send out an email and we'll copy in interested parties like the Chairman/Financial Controller who is not on our main kind of office email set up. So, we will include people and there is quite a lot of group celebration by email if you like." [Informant \#10]

Individualistic and informal practices. Furthermore, we observed the majority of event interpretation and acknowledgement at entrepreneurial firms to be informal and determined by a single individual. 
Again, these ad-hoc acknowledgements were one-time responses (or lack of response) that were apparently never propagated to others or revisited. We consistently observed informal, one-off, and most importantly, de-emphasised practice as normal. For example, in the excerpt below, we see the primary characteristic is the individual effort to downplay the significance of event interpretation via muted or absent response:

"So, the decision to delay the launch was made by myself. I spoke to our marketing team and, without giving them the details, asked them to clarify if a later launch was acceptable. Clearly, they got concerned just by me saying that. They validated my thought process, partly just to give me comfort in my decisionmaking process. And that was it. [I] decided we were going to delay our launch and we were probably a bit glum for about half an hour" [Informant \#16]

In another example, a failed meeting between nascent venturing groups is informally acknowledged via shared experience to generate a consensual re-interpretation:

"So, we met that day and having the others at the meeting was a disaster, and we acknowledged that after, like, immediately after. The potential partner was not a fit whatsoever in contribution or in style, and the others were not contributing and just seemed sort of not interested, like they were there because their boss made them be there. So, the three of us had emailed after that meeting and had said 'let's have lunch tomorrow just the three of us to discuss this,' which we did and at that lunch meeting we said, we all agreed that the other guy was out and that we should've just had the meeting with the three of us." [Informant \#11]

The practice of shared loss serves as validation of prior plans by identifying processes and contributions that were not relevant. The narrative constructed above highlights a form of 'bouncing back' where, in effect, the interpretation of failure is converted into a justification of the team's existence.

\section{Interpretation bias}

Across our dataset, we observed biases in event interpretation as a consequence of the uncertain entrepreneurial context:

Rationalisation. Consistent with prior studies (Caldwell and O'Reilly, 1982; Cardon et al., 2011), which describe failure rationalisation as the explanation or externalisation of negative event outcomes, practices in our data included rationales of failure as learning opportunities, necessary experimentation and unavoidable failure due to endogenous or exogenous factors. Re-interpreting failure as a learning opportunity may be aligned with resiliency and perceptions of character building. Some informants stated that failure is associated with risk-taking and experimentation inherent to the entrepreneurial context:

"You can't have perfect knowledge in advance... if stuff goes wrong, you can't get too bent out of shape by it because it's going to go wrong. Just like you can't be too busy patting yourself on your back when things go right, it's just an experiment." [Informant \#21]

In contrast with failure rationalisation, we found numerous examples of success rationalisation. These took two forms. In the first, event re-interpretation validates prior expectations and 
immediately sets new, higher expectations. This 'expectation creep' may stem from the perceived inherent vulnerability of the organisation. Success is a justification for setting new goals rather than an opportunity for reflection or congratulatory feeling:

"How it was acknowledged... like most stuff in this company is, 'what's our next project?' is how... The bars are so high at times and, sometimes, I think the development group sets them higher for themselves than I could possibly set them, but I think that the bars are set so high that we're almost onto the next thing the moment this thing launches." [Informant \#1]

In the second, our analysis revealed that many narratives of success in entrepreneurial firms were directly associated with the survival of the organisation. In particular, success is necessary. When successful event outcomes are required and therefore expected, celebration appears to be superfluous.

Event blurring and re-interpretation. Our analysis also revealed informants to be engaging in an interpretive process in which the nature or meaning of event effects were blurred or completely re-interpreted. In some cases, we witnessed the event outcome level to be blurred, such as when individual successes are interpreted or acknowledged at the firm level. In other instances, we observed the cause-effect nature of events to be re-interpreted resulting in the event outcome becoming a validation or justification of prior actions. Information-poor contexts and limited experience lead organisational actors to counter-evident interpretations. In one story of selfidentified success, the founder describes an early sales meeting and subsequent event interpretation:

"The experience... it didn't go quite according to plan. It didn't end with him asking me to place any people, in fact he kind of asked me some quite difficult questions, which made me go back and revise what my business was all about and also who my target customer was... I went home, and I spoke to my brother, who was helping me quite a bit at the time. We were both very pleased that I had that meeting and really to celebrate... because there was no money, nothing, no placements were requested, I think I probably just had a coffee and a cake! Yes, sadly there was no champagne!" [Informant \#14]

Despite obvious failure, the event outcome is socially re-constructed as successful and cause for celebration. The blurring of organisational signposts at entrepreneurial firms influences interpretation and subsequent behaviours. An event outcome that would be quickly labelled 'failure' in a traditional organisational context may be dramatically re-interpreted in an entrepreneurial context.

Re-interpreting failure as a learning opportunity may be closely aligned with resiliency and perceptions of character building. Participants re-interpreted failure as an unavoidable outcome, based on either circumstances or outside the immediate sphere of control:

"So, there was that downgrade that was marked, it's something we discuss in our pod meetings... but I mean, once it happens there's not much you can do if the client decides so; in that sense it was a failure at keeping them at the highest level of engagement. But, I mean, in the end they're still engaged, which I guess is a success, a plus... you don't want that to happen, but that is the nature of the business." [Informant \#26] 


\section{Acknowledgement bias}

We also witnessed biases in event acknowledgement. In particular, acknowledgement bias either exaggerates or inhibits event acknowledgement to reflect and reinforce received norms:

"Yeah, I just went home and just slept... we were just both so tired and I just knew that it was a really bad idea to start throwing your weight around, having a go at people, or pointing and blaming people, whether that's just two of us or whether that's a larger amount of people, so yeah, I just went home and accepted it." [Informant \#15]

Our dataset revealed de-emphasis of events and muted forms of acknowledgement. In the following example, a founder reflects on the success of a mission critical, year-long project linking the firm's primary product to Facebook:

“...how we've acknowledged success to date is largely, we have a lot of different opportunities to talk to the organisation about what's important, so we have all hands - we have one tomorrow... about once a month, a very short 15 min or so. So, tomorrow we'll be doing a demo of the new tool... going forward, we are going to have more formal acknowledgements... everything from I am the master of my domain $t$ shirt to tchotchkes... I might just give them a nice pen or something to publicly acknowledge "[Informant \#21]

Here, the primary form of acknowledgement was public recognition during an 'all-hands' meeting. Emotional celebration is inhibited, limited to a previously scheduled event during which the successful tool is demonstrated. The founder then describes firm-centric gifting as formal acknowledgement, which both inhibits the meaning of the celebration. Gifting company-labelled products reflects the needs and benefits of the organisation rather than celebrates the individuals or groups that drove success.

In the following example, even after blame is placed on seasonality, the CEO becomes complicit in the process of de-emphasising acknowledgement:

\footnotetext{
"So, we missed our cue for our numbers pretty significantly, not because of any business issue but because there's a seasonality to our business that we hadn't incorporated into the forecast... the way I communicated that to the organisation was very informal and sort of under the breath, far more under the breath than I should have, in retrospect, communicated. It was, 'we didn't hit our financials, the business is more seasonal than we thought, you know, it doesn't impact any business health." [Informant \#7]
}

In this case, missing financial targets was informally communicated and passed off as insignificant, despite a real impact upon the firm. Unlike highly ritualised event interpretation and acknowledgement at large organisations, we consistently observed informal, one-off, and most importantly, de-emphasised practice as normal. The primary characteristic of this acknowledgement inhibition was the individual effort to downplay the significance of event interpretation via muted or absent responses, which reflects an acknowledgement bias.

The combination of interpretation bias and acknowledgement bias presents a novel approach to understanding the evolution of organisational identity at entrepreneurial firms under uncertainty. In the following Discussion section, we explore this approach in more depth, including a potential interpretation for the emergence of organisational identity characteristics (Figure 1). 


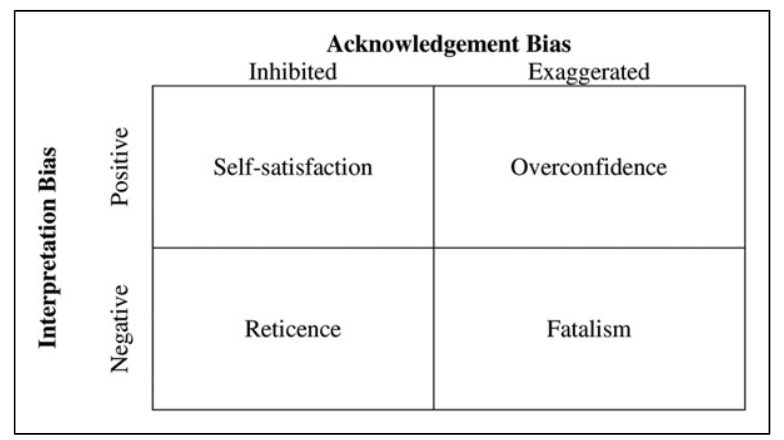

Figure I. Emergent organisational characteristics arising from interpretation and acknowledgement biases.

\section{Discussion}

We extend our analysis to further delineate how founders and managers in entrepreneurial firms interpret and acknowledge successful and failed events. Specifically, we reveal the distinct characteristics of acknowledgement practices at entrepreneurial firms, distinguishing them from practices at large organisations. Next, we further examine how perceived environmental uncertainty influences interpretation and acknowledgement of events and outcomes. Specifically, we discuss the role of uncertainty and the generation of individual interpretative and acknowledgement biases, which leads to emergent organisational characteristics. We highlight these relationships in Figure 2, linking uncertainty to individual event interpretation and acknowledgement, emergent organisational characteristics and organisational identity.

By extending recent research investigating entrepreneurial success and failure (Angel et al., 2018; Jenkins and McKelvie, 2016), our study imparts four contributions to organisational behaviour scholarship. First, we uncover the distinct characteristics of individual event interpretation and acknowledgement in entrepreneurial contexts, which differs from responses to event outcomes in large, stable organisations. Second, we highlight how uncertainty shapes individual event interpretation and acknowledgement at entrepreneurial firms. Third, we show how this uncertainty drives individual interpretation and acknowledgement biases. Fourth, we suggest that these biases generate emergent organisational characteristics, which has important implications for organisational identity at entrepreneurial firms.

\section{Event interpretation and acknowledgement at entrepreneurial firms}

Our analysis of how founders and managers interpret and acknowledge successful and failed events in entrepreneurial firms reveals behaviour distinct from practices at large organisations, which is nonetheless critical to organisational characteristics and identity. More specifically, we refer to this event response phenomenon in entrepreneurial contexts as acknowledgement practice, which we define as the ad-hoc action (or inaction) of organisational actors and groups responding to observed events.

In large, relatively stable organisations, event interpretation and acknowledgement are planned, repeated actions that are enacted by a group of actors (Dacin et al., 2010; Islam and Keliher, 2018; Kulkarni, 2020). Yet, our findings show acknowledgement practices to have four distinctive characteristics, which differ from event interpretation and acknowledgement in large, organisations 


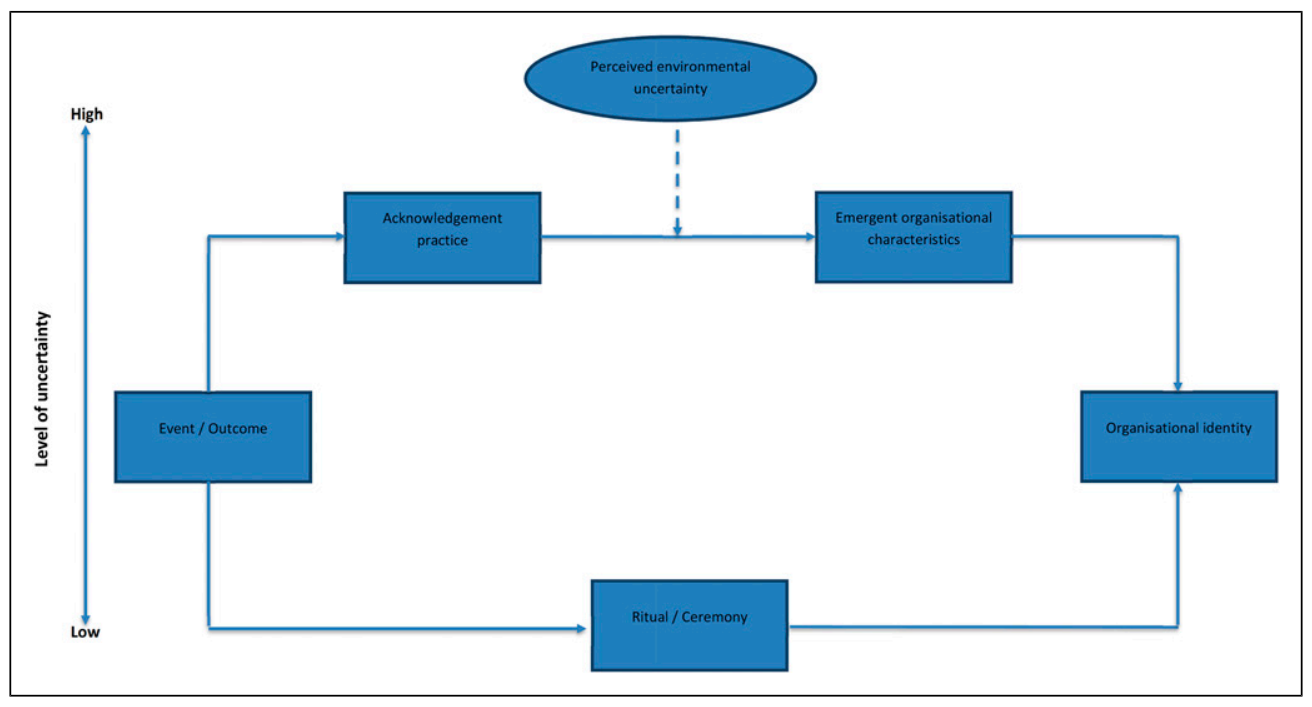

Figure 2. Link between uncertainty, event interpretation and acknowledgement, emergent organisational characteristics and organisational identity.

(Isabella, 1990). First, they are specific, one-time reactions, rather than repeated responses (i.e. adhoc). Second, they are immediate, often improvised, or vacated actions, where little or no purposeful planning takes place. Third, unlike event interpretation and acknowledgement at large firms, acknowledgement practice at entrepreneurial firms tends to be individualistic. In most cases, the response or practice was decided upon, undertaken, or inhibited by an individual. Fourth, within entrepreneurial firms, the majority of acknowledgement practices are informal. However, as entrepreneurial firms navigate the entrepreneurial process, and both develop and mature, we can expect that some informal acknowledgement practices will evolve into formal practices (Feldman and Pentland, 2003).

In entrepreneurial firms, where norms and behavioural patterns are embryonic, acknowledgement practice disproportionately drives behaviour. It is important to recognise that organisational events are fundamentally affect-neutral. Individuals ascribe emotional content to an event within a social context (Peterson, 1998; Peterson and Smith, 2000). Affect generation and attribution operate through the combination of interpretation and acknowledgement. This process is important at entrepreneurial firms for three reasons. First, in the small group context of entrepreneurial activity, ad-hoc acknowledgement practice has a disproportionate impact on group-level understanding of organisational events (Maitlis and Christianson, 2014). Second, the norms that guide, frame and validate interpretations and acknowledgement are few and fluid (Forbes, 2005). Third, the high level of uncertainty common to entrepreneurial contexts may affect interpretations and acknowledgement in unpredictable ways (Packard et al., 2017).

\section{Uncertainty: Impact upon event interpretation and acknowledgement}

In exploring the role of uncertainty in acknowledgement practice at entrepreneurial firms, we rely on the use of Milliken's (1987) framework for perceived environmental uncertainty. This framework is especially helpful because we are only interested in how perception of environmental uncertainty 
influences individual behaviour and response (Packard et al., 2017). Our research into acknowledgement practice reveals how perceived uncertainty influences both the interpretation and acknowledgement of events in three distinct ways.

First, in our study, the indeterminate nature of event outcomes may be attributed to time lags between events and observations, limited communication or observational mechanisms, unequal knowledge across the organisation and inability to assess event outcomes due to incomplete or inaccessible information (Townsend et al., 2018). These represent instances of event-effect uncertainty, where organisational actors are unable to apply a logically consistent value-laden interpretation on organisational events (Packard et al., 2017).

Second, in entrepreneurial firms, individuals may lack clear direction and feedback about success or failure in the current, unformed context (i.e. less developed structures) of the venture. This may derive, in part, from state uncertainty associated with limited information and unfamiliar contexts. In fact, these individuals may not utilise fixed goals, but may adjust intended outcomes to match the evolving resource portfolio of the organisation (Giones et al., 2020; Sarasvathy, 2001).

Both state uncertainty and event-effect uncertainty influence event outcome interpretation. As discussed previously, reinterpretation changes the valence of the perceived interpretation. However, interpretation significance can also be moderated. Most of the ad-hoc acknowledgement practice activities we recorded showed an inhibiting effect. While individuals in entrepreneurial firms may extrapolate from limited data in decision-making, they do not appear to overestimate their resource base or apply counterfactual arguments to the leveraging of that resource base (Arora et al., 2013; Baron, 2000). When firm participants are unable to ascertain outcome valence, they imbue events with a more neutral rather than extreme interpretation.

Third, we reveal that response uncertainty affects acknowledgement practice through a different mechanism. In particular, uncertainty reduction theory suggests that individual efforts to reduce discomfort associated with uncertainty leads to the acceptance of ambiguous norms (Smith et al., 2007). Specifically, unlike state- and event-effect uncertainty, which blur the observer's understanding of event valence and significance, response uncertainty influences the organisational actor's understanding of how other actors at the organisation will respond to ad-hoc acknowledgement practice (Milliken, 1987; Packard et al., 2017).

We also find that acknowledgement practices are not a purely linear process initiated by observation of event outcomes and terminated at the point of behavioural reaction. In any organisational context, participants are constantly observing event outcomes at multiple levels and generating interpretations that are interspersed and asynchronous (Isabella, 1990; Packard et al., 2017). When uncertainty is high, the development of acknowledgement practices is dynamic and holistic rather than static and linear, which leads to biases associated with event interpretation and acknowledgement.

\section{Interpretation and acknowledgement biases}

Biases are central to entrepreneurial decision-making and action (Zhang and Cueto, 2017). Founders within entrepreneurial firms have been shown to display greater decision-making biases than individuals in large organisations (Busenitz and Barney, 1997). However, despite the importance of biases to entrepreneurship, the different types of biases, and their relationship to firm outcomes, warrants further discussion (Shepherd et al., 2015; Zhang and Cueto, 2017).

Building upon Shepherd et al., (2015) and Zhang and Cueto (2017), our analysis has revealed how uncertainty associated with acknowledgement practice reveals biases. Specifically, we show how these biases influence the development of emergent characteristics in entrepreneurial firms, 
which has important implications for organisational identity. Event interpretation and acknowledgement may be driven by individual and community-level emotional context (Angel et al., 2018), whether associated with permanent traits or temporary affect. This is critical for understanding the development of emergent characteristics in entrepreneurial firms.

Interpretation bias. Uncertainty may bias individual interpretation of events (Packard et al., 2017). Interpretation bias imposes a positive or negative valence onto events as part of the process required to maintain and reinforce extant organisational narratives. Research has demonstrated the human inclination to adjust interpretations to maintain consistent narratives rather than adjust the narrative to accommodate new data (Simon, 2004).

A positive individual interpretive bias would be expected in situations in which individual and organisational goals are congruent. For example, organisational actors at entrepreneurial firms generally develop affinity for the exploitation of the firm's innovations (George and Bock, 2008). The social construction of heroic narrative around overcoming obstacles to success could facilitate positive valence interpretation bias. In contrast, when individual and organisational goals are misaligned, or individuals have been adversely affected by perceived outcomes, individuals could generate further negative valence in the interpretation and acknowledgement of events. Organisations formed during periods of resource scarcity, or affected by significant early setbacks or failures, might be prone to negative valence interpretation bias.

Acknowledgement bias. At the same time, uncertainty may bias individual and communal acknowledgement response (Townsend et al., 2018). Acknowledgement bias either exaggerates or inhibits event acknowledgement to reflect and reinforce received norms. Inhibited acknowledgement can become an important characteristic of organisational identity, in which success and failure are not moments to dwell upon (Walsh and Cunningham, 2017); they are key organisational practices that signal to members the importance of moving forward. Alternately, organisational actors may exaggerate the significance of event outcomes to support extant narratives (Gabriel, 2004). This could take the form of boosting morale or motivating from failure. These biasing effects, instigated by uncertainty, highlight how celebration and loss are key forms of practice that are interpreted and acknowledged within entrepreneurial firms to shape organisational identity.

The combination of interpretative biases (positive or negative valence) and acknowledgement biases (inhibited or exaggerated) suggest four broad emergent organisational characteristics, which have important implications for organisational identity. These are shown in Figure 1 and discussed below.

Positive and inhibited: Self-satisfaction. We identify the combination of positive interpretation bias and inhibited acknowledgement bias as 'self-satisfaction'. This combination is facilitated by the prevalence of electronic communication (Black and Edwards, 2000). In our dataset, founders and managers heavily utilised electronic communication modes to report and respond to successes. However, celebration is generally limited to posting of follow-up information or positive expressions.

The story below recalls the first major success of a new manager's effort to expand the firm's presence in a specific online community through the creation and dissemination of firm-specific content:

"So, we finally launched this quarter a product... we just published it on Monday... within two hours of putting the release on the wire we had calls from half a dozen media organisations... we had like 15 
pieces of coverage, and I was just like, sent an email to the entire company, like, 'wow, look at all this!' And what was really awesome was that the founder who I worked on with this, sent me an email and he was like 'wow, you were really right when you said this was going to be big, ' which was funny, because I actually put up on my Twitter that the three most beautiful words in the human language might just be 'you were right' [laugh]!' [Informant \#25]

In the highly depersonalised context in which these individuals' function, this new manager initiates the celebratory practice via the reporting email, which the entrepreneurial founder normalises by responding with email rather than in person. Further, because the founder's email restricts celebration to their dyadic interaction, rather than reporting more broadly, it is up to the new manager to initiate communal celebration, which she does via Twitter. In large organisations, traditional celebratory practice communication is directed to specific organisational members (Anand and Watson, 2004; Rosen, 1988). Yet, the type of celebration described here is inhibited within the organisational perspective because it is personal expression communicated only to those people who have previously chosen to receive information from the informant, whether they are within the organisation or not. Organisational celebration is partly or entirely replaced with social, but impersonal, celebration centred on the individual.

Negative and inhibited: Avoidance. We identify the combination of negative interpretation bias and inhibited acknowledgement bias as 'avoidance'. Organisational actors may tend to avoid directly confronting negative situations. Rather than perceive an opportunity for organisational change or development, organisational actors imbue the event outcome with negative interpretation and inhibited acknowledgement bias to avoid directly confronting the situation. For example, avoidance can be a useful strategy for entrepreneurs to overcome fear of failure whereby they avoid specific situations to protect themselves (Walsh and Cunningham, 2016). Recent studies have shown avoidance to be a defensive strategy to relieve emotional tension (Radu-Lefebvre and Randerson, 2020). The establishment and reinforcement of the norms associated with this cycle may be quite powerful. Avoidance is linked to the perception that acknowledgement, and mourning in particular, is inefficient at the firm level and represents a loss of managerial control. In contrast to prior findings on grieving at organisations (Shepherd, 2009; Ucbasaran, et al., 2013), these organisational actors are, in effect, repressing the grieving process.

In the example below, a CEO specifically brought in to professionalise a struggling online business found himself conforming to extant norms and practices. Rather than enforce accountability, he avoided the event outcome altogether:

"There was little to no response to this because this company has a history of missing plans dra-
matically, that's why the Board brought me in... there were these sort of aspirational plans and the
budgets were tiny, way off versus expectations. So, there was a little bit of a problem... I didn't
communicate it in a way that was as serious as I should have and I think I've, therefore, let people off the
hook in an environment where they already feel like they're off the hook a little bit." [Informant \#7]

Negative and exaggerated: Fatalism. We also identify the combination of negative interpretation bias and exaggerated acknowledgement bias as 'fatalism'. The emergence of this combination is expressed by individuals anticipating inevitable event outcomes, usually in the form of failure. In particular, entrepreneurs view venture failure as inevitable due to insurmountable problems (Singh et al., 2015). More specifically, entrepreneurs reinterpret uncertainty and, fatalistically, accept that 
certain event outcomes are completely beyond their own control, which aligns with recent research (Ganzin et al., 2019).

In the following example, a firm founder described how a funding proposal was not wellreceived:

“...the proposal got assessed and this is when things started to go badly wrong because it got assessed by a person that wasn't competent to assess it. So, it's like the blind leading the blind... biotech person has a proposal in photonics which she gives to some electrical power engineering type person who says it's a crap power proposal... I wrote back to them and said, 'this is the most appalling thing I've ever seen; I've got ten years of experience, I know what I'm talking about, you clearly don 't know what you're doing.' And the conclusion of this letter was, 'just give me my proposal back because you don 't know what you're doing." [Informant \#9]

When the funding entity responded by offering to have the proposal re-assessed by someone with field-specific expertise, the founder refused, on the assumption that it would not be successful. However, recent studies have suggested that entrepreneurs that anticipate failure may be better prepared to plan for it (Jenkins and McKelvie, 2017)

Positive and exaggerated: Overconfidence. Finally, we recognise the combination of positive interpretation bias and exaggerated acknowledgement bias as 'overconfidence'. This is an important finding because overconfidence has been extensively reported in entrepreneurial contexts (Cooper et al., 1988; Gudmundsson and Lechner, 2013; Invernizzi et al., 2016).

In this example, even the explicit awareness of organisational actor error does not prevent management from attempting to interpret event outcomes over-optimistically:

"So, the failure happened because some product ideas that we had failed, so it was an error... we made some choices that didn't turn out to be the right choices... the person who's monitoring the financials was sort of asleep at the wheel [laugh] for about six weeks. The reason why she was asleep at the wheel was... she is running marketing and sales and was, sort of, overwhelmed and just didn't connect and we have a part time CFO... so they weren't connecting the dots and we're also optimists on our management team too much, so when I got the bad news, I assumed it was a finance error, like an error, not actually sort of the business driver. So, there was a level of optimism in the company around the failure" [Informant \#7]

The dominant theory of overconfident entrepreneurs assumes that individual traits drive organisational behaviour (Bernardo and Welch, 2001). Studies suggest, however, that opportunistic behaviour may be driven by recent events (McCarthy et al., 1993) and transitory states such as regret (Hatak and Snellman, 2017; Marchiori and Warglien, 2008). Further, behavioural traits are not necessarily static or permanent (Delgado-Gómez et al., 2010). This suggests that a theory of 'overconfident entrepreneurs' driving behaviour within entrepreneurial firms is likely to be simplistic.

Our findings suggests a complementary approach to understanding the prevalence of overconfidence. In particular, our analysis suggests that within entrepreneurial firms, overconfidence may emerge as the result of a path dependent process combining efforts to reduce perceived uncertainty with acceptance of otherwise ambiguous norms. In other words, our findings reveal that overconfidence at organisations can emerge de novo from event interpretation and acknowledgement under uncertainty rather than derive from prior entrepreneurial traits. This is consistent 
with a view of entrepreneurs as products of their organisation (Audia and Rider, 2006), and represents an important area for additional research.

Figure 2 illustrates the links between uncertainty, individual event interpretation and acknowledgement, emergent organisational characteristics, and organisational identity. More specifically, it reveals that when uncertainty is high, organisational actors respond to events and outcomes through ad-hoc, informal, immediate, and individualistic acknowledgement practices. This interpretive and acknowledgement process may be biased by state, event-effect, and/or response uncertainty, resulting in emergent organisational characteristics. These individual responses to events and outcomes, when uncertainty is high, are closely linked to the organisation's identity. In contrast, in situations of low uncertainty, event interpretation and acknowledgement are planned, repeated actions that are enacted by a group of actors through ritual and ceremony. Both ceremony and ritual are important organisational functions that transmit organisational identity.

\section{Limitations}

Our qualitative, exploratory study has several limitations and in the following section, we suggest how future research could address opportunities to build on our findings.

Although the dataset provides a reasonable basis for coding and theory-building, it is primarily limited to firms developing or commercialising novel technologies or product innovations, and only in relatively large urban contexts in the United States and United Kingdom. Additionally, the dataset is cross-sectional. Furthermore, it is also possible that unknown biases were introduced by the opportunistic selection of firms.

We did not capture detailed sociodemographic data about the interview participants. Although some data was available to us (e.g. tenure at the organisation), or could be somewhat clearly inferred from names and audio recordings (e.g. gender), we have not reported these to avoid any unintended inferences. We did not explicitly incorporate such factors into our coding process; the post-hoc comparison of such factors across node frequency would not be based on valid hypotheses framed from prior research.

Similarly, the open-ended coding of the dataset did not generate significant nodes for concepts that might otherwise have seemed relevant, including leadership and culture. It is tempting to return to the dataset to seek these out, but such an effort would invalidate the open-ended nature of the original coding process.

\section{Directions for future research}

Our findings raise important questions. First, when and why do some ad-hoc acknowledgement practices become routinised into ritual, while others do not? Does acknowledgement practice eventually become codified into ritual/ceremony, or does it get replaced by new ritual/ceremony? A theory of routines suggests the former is likely (Feldman and Pentland, 2003). This would be especially important at high-growth firms, where the successful absorption of significant new employee populations creates a complex context for testing norms and interpreting events. Second, do the bias combinations have a greater impact upon identity and outcomes than imprinting effects or founder affect? Under what conditions does one or the other dominate? This has significant implications for theories of entrepreneurial action and venture founding. Third, how are ad-hoc acknowledgement practices, and interpretation and acknowledgement biases, linked to firm 
outcomes such as failure or growth? It seems likely that the emergence of affect resulting from socially constructed narratives could significantly influence venture success or failure.

Future research could address key gaps and limitations identified by our study. Of particular interest would be a structuration approach to the interaction of culture, leadership and acknowledgement practice. For example, can entrepreneurial leaders use culture to direct acknowledgement practice in developing ventures? Culture in smaller, developing firms is relatively fluid and unformed; the subjective and ad-hoc nature of acknowledgement practice suggests that it could be leveraged by observant and prepared leaders to generate more resilient and self-actuated teams. The relative vulnerability of early-stage ventures would make this a valuable skill and asset if research validated the relationship.

This suggests another critical opportunity for further research - exploring how acknowledgement practice is correlated, or even causally related, to firm-level outcomes. Our findings suggest an intermediary element of organisational identity (Figure 2), but this would only be of substantive importance to entrepreneurial leaders (and, perhaps, private equity investors), if there are implications for firm-level performance.

Additionally, the COVID-19 pandemic, which occurred after the fieldwork and analysis in this paper has placed organisations under intense uncertainty. Exploring acknowledgement practices in the aftermath of COVID-19 could further our understanding of the link between acknowledgement practices, emergent organisational characteristics and organisational identity. Of particular interest would be to understand how organisational leaders have responded to this uncertainty and the role acknowledgement practices have played in shaping organisational culture (Spicer, 2020) and identity (Ashforth, 2020).

To address these future research areas, interpretative phenomenological research (Cope, 2011), as well as participant observations (Dacin et al., 2010) will prove fruitful. Such qualitative approaches, coupled with firm-level data (e.g. business model, turn-over, and growth), can help shed further light onto acknowledgement practice at entrepreneurial firms. At the same time, quantitative approaches will provide the opportunity to seek specific correlations between firm-level data and acknowledgement practices.

\section{Conclusion}

This paper presents a novel picture of acknowledgement practice at entrepreneurial firms. We investigated interpretation and acknowledgement of events within entrepreneurial firms to extend prior research on responses to events within large, stable organisations, which present as ceremony and ritual. We explored the characteristics and processes of acknowledgement practice under uncertainty and showcased how interpretation and acknowledgement biasing generates emergent organisational characteristics. These characteristics emerge from ad-hoc, informal, immediate, and individualistic practices of celebration and loss during firm organising and development. Consequently, they have important implications for organisational identity. Therefore, our research emphasises the importance of investigating seemingly ephemeral events and processes, especially during periods of rapid change and adaptation. Our findings suggest that theories of entrepreneurial psychology, imprinting and ritual should be complemented by sociological and group dynamics perspectives that reveal the complexities of organisational behaviour amidst uncertainty.

Of particular interest to entrepreneurship researchers and practitioners is our exploration of the behavioural mechanisms by which organisational actors, particularly founders, interpret and acknowledge events and propagate meaning. Recent research has demonstrated that shared mental 
models influence organisational exploration and exploitation innovation activities (Dao et al., 2017). These results, however, overlook a key aspect of cognitive mechanism - the development and communication of a shared understanding of organisational purpose and identity. Our findings show that the organisational identity may be affected by interpretation and acknowledgement biases. Optimising organisational practices requires entrepreneurial managers to recognise or even control how such biases influence identity.

Practically, celebration and loss are inescapable psychological processes at organisations but are especially important at entrepreneurial ventures where organisations lack a coherent or established identity. Small group dynamics, executive influence and resource scarcity increase the importance of event interpretation and acknowledgement. If entrepreneurial firms fail to appropriately recognise success and failure, formative organisational identity may not be grounded in an appropriate, shared base of experience. Celebration and loss rituals, even when de-emphasised, are still formative practices that shape individual and community-level sense-making. Without shared celebration and loss, employees may have a skewed sense of what is important to the success of the venture. The emergence of organisational characteristics from event interpretation and acknowledgement under uncertainty may have a direct impact upon how key individuals at entrepreneurial firms make important decisions.

\section{Acknowledgements}

We thank colleagues from the Adam Smith Business School (University of Glasgow) for their comments and guidance on earlier versions of this paper. We extend our thanks to the two anonymous reviewers for their considered comments and suggestions.

\section{Declaration of conflicting interests}

The author(s) declared no potential conflicts of interest with respect to the research, authorship, and/or publication of this article.

\section{Funding}

The author(s) received no financial support for the research, authorship, and/or publication of this article.

\section{ORCID iD}

David Johnson (D) https://orcid.org/0000-0002-5378-0982

\section{References}

Anand N and Watson MR (2004) Tournament rituals in the evolution of fields: the case of the Grammy awards. Academy of Management Journal 47(1): 59-80.

Anderson AR and Warren L (2011) The entrepreneur as hero and jester: enacting the entrepreneurial discourse. International Small Business Journal 29: 589-609.

Angel P, Jenkins A and Stephens A (2018) Understanding entrepreneurial success: a phenomenographic approach. International Small Business Journal 36(6): 611-636.

Arora P, Haynie JM and Laurence GA (2013) Counterfactual thinking and entrepreneurial self-efficacy: the moderating role of self-esteem and dispositional affect. Entrepreneurship Theory and Practice 37(2): $359-385$.

Audia PG and Rider CI (2006) Entrepreneurs as organizational products: revisited. In: Baum JR, Frese M. and Baron RA (eds.), The Psychology of Entrepreneurship. Mahwah, NJ: Lawrence Erlbaum Associates, pp. $113-130$. 
Ashforth BE (2020) Identity and identification during and after the pandemic: how might COVID-19 change the research questions we ask? Journal of Management Studies 57(8): 1763-1766.

Baker T and Nelson RE (2005) Creating something from nothing: resource construction through entrepreneurial bricolage. Administrative Science Quarterly 50(3): 329-366.

Baker T, Miner AS and Eesley DT (2003) Improvising firms: bricolage, account giving and improvisational competencies in the founding process. Research Policy 32(2): 255-276.

Baron RA (2000) Counterfactual thinking and venture formation. Journal of Business Venturing 15(1): 79-91.

Barr PS, Stimpert JL and Huff AS (1992) Cognitive change, strategic action, and organizational renewal. Strategic Management Journal 13: 15-36.

Bauer M (1996) The narrative interview: Comments on a technique for qualitative data collection. In: Papers in Social Research Methods - Qualitative Series. London: London School of Economics, Methodology Institute, vol. 1.

Bell E and Taylor S (2011) Beyond letting go and moving on: new perspectives on organizational death, loss and grief. Scandinavian Journal of Management 27(1): 1-10.

Bernardo A and Welch I (2001) On the evolution of overconfidence and entrepreneurs. Journal of Economics \& Management Strategy 10(3): 301-330.

Beyer JM and Trice HM (1987) How an organization's rites reveal its culture. Organizational Dynamics 15(4): $5-24$.

Black JA and Edwards S (2000) Emergence of virtual or network organizations: fad or feature. Journal of Organizational Change Management 13(6): 567-576.

Boje DM (1995) Stories of the storytelling organization: a postmodern analysis of disney as"Tamara-Land". Academy of Management Journal 38(4): 997-1035.

Brown A (2017) Identity work and organizational identification. International Journal of Management Reviews 19(3): 296-317.

Busenitz LW and Barney JB (1997) Differences between entrepreneurs and managers in large organizations: biases and heuristics in strategic decision-making. Journal of Business Venturing 12(1): 9-30.

Byrne O and Shepherd DA (2015) Different strokes for different folks: entrepreneurial narratives of emotion, cognition, and making sense of business failure. Entrepreneurship Theory and Practice 39(2): 375-405.

Caldwell DF and O'Reilly CA (1982) Responses to failure: the effects of choice and responsibility on impression management. Academy of Management Journal 25(1): 121-136.

Cardon MS and McGrath RG (1999) When the going gets tough toward a psychology of entrepreneurial failure and re-motivation. Frontiers of Entrepreneurship Research 29(4): 58-72.

Cardon MS, Stevens CE and Potter DR (2011) Misfortunes or mistakes?: Cultural sense-making of entrepreneurial failure. Journal of Business Venturing 26(1): 79-92.

Charmaz K (2006) Constructing Grounded Theory: A Practical Guide Through Qualitative Analysis. London, UK: Sage Publications Ltd.

Ciuchta MP, O'Toole J and Miner A (2021) The organizational improvisation landscape: taking stock and looking forward. Journal of Management 47(1): 288-316.

Coffey A and Atkinson P (1996) Making Sense of Qualitative Data: Complementary Research Strategies. Thousand Oaks: Sage Publications Ltd.

Cooper AC, Wood CY and Dunkelberg WC (1988) Entrepreneurs' perceived chances for success. Journal of Business Venturing 3(2): 97-108.

Cope J (2011) Entrepreneurial learning from failure: an interpretative phenomenological analysis. Journal of Business Venturing 26(6): 604-623.

Corley KG and Gioia GA (2004) Identity ambiguity and change in the wake of a corporate spin-off. Administrative Science Quarterly 49(2): 173-208. 
Cornelissen JP, Haslam SA and Balmer JMT (2007) Social identity, organizational identity and corporate identity: towards an integrated understanding of processes, patternings and products. British Journal of Management 18(s1): S1-S16.

Dacin TM, Munir K and Tracey P (2010) Formal dining at Cambridge colleges: linking ritual performance and institutional maintenance. Academy of Management Journal 53(6): 1393-1418.

Dao MA, Strobl A, Bauer F, et al. (2017) Triggering innovation through mergers and acquisitions. Group \& Organization Management 42(2): 195-236.

Delgado-Gómez D, Sukno F, Aguado D, et al. (2010) Individual identification using personality traits. Journal of Network and Computer Applications 33(3): 293-299.

Dey I (2007) Grounding categories. In: Bryant A and Charmaz K (eds), The Sage Handbook of Grounded Theory. London, UK: Sage Publications Ltd.

Di Domenico M and Phillips N (2009) Sustaining the ivory tower: oxbridge formal dining as organizational ritual. Journal of Management Inquiry 18(4): 326-343.

Domurath A, Patzelt H and Liebl A (2020) Does negative feedback impact new ventures' organizational identity? The role of founding teams' human capital and feedback source. Journal of Business Venturing 35(3): 105987.

Dutton JE and Dukerich JM (1991) Keeping an eye on the mirror: Image and identity in organizational adaptation. Academy of Management Journal 34(3): 517-554.

Eggers JP and Song L (2015) Dealing with failure: serial entrepreneurs and the costs of changing industries between ventures. Academy of Management Journal 58(6): 1785-1803.

Ernst J and Schleiter AJ (2019) Organizational identity struggles and reconstruction during organizational change: narratives as symbolic, emotional and practical glue. Organization Studies 42(6): 891-910.

Feldman MS and Pentland BT (2003) Reconceptualizing organizational routines as a source of flexibility and change. Administrative Science Quarterly 48(1): 94-118.

Forbes DP (2005) Managerial determinants of decision speed in new ventures. Strategic Management Journal 26: 355-366.

Gabriel Y (2000) Storytelling in Organizations: Fact, Fictions, and Fantasies. Oxford, UK: Oxford University Press.

Gabriel Y (2004) Narratives, stories and text. In: Grant D, Hardy C, Oswick C, et al. (eds), The Sage Handbook of Organizational Discourse. London: Sage Publications Ltd, pp. 61-77.

Ganzin M, Islam G and Suddaby R (2019) Spirituality and entrepreneurship: the role of magical thinking in future-oriented sensemaking. Organization Studies 41(1): 77-102.

Garreau L, Mouricou P and Grimand A (2015) Drawing on the map: an exploration of strategic sensemaking/ giving practices using visual representations. British Journal of Management 26(4): 689-712.

George G and Bock AJ (2008) Inventing Entrepreneurs. Saddleback. New Jersey: Prentice-Hall Pearson.

Gilson LL and Davis DW (2019) Managing in an age of complexity and uncertainty. Group \& Organization Management 44(2): 243-246.

Gioia DA and Thomas JB (1996) Identity, image, and issue interpretation: sensemaking during strategic change in academia. Administrative Science Quarterly 41: 370-403.

Gioia DA, Corley KG and Hamilton AL (2012) Seeking qualitative rigor in inductive research: notes on the gioia methodology. Organizational Research Methods 00(0): 1-17.

Gioia DA, Schultz M and Corely KG (2000) Organizational identity, image, and adaptive instability. Academy of Management Review 25(1): 63-81.

Giones F, Brem A, Pollack JM, et al. (2020) Revising entrepreneurial action in response to exogenous shocks: considering the COVID-19 pandemic. Journal of Business Venturing Insights 14: e00186.

Glaser BG (1965) The constant comparative method of qualitative analysis. Social Problems 12(4): 436-445. 
Glaser BG (2001) The Grounded Theory Perspective: Conceptualization Contrasted with Description. Mill Valley, CA: The Sociology Press.

Gudmundsson SV and Lechner C (2013) Cognitive biases, organization, and entrepreneurial firm survival. European Management Journal 31(3): 278-294.

Habersang S, Küberling J, Reihlen M, et al. (2019) A process perspective on organizational failure: a qualitative meta-analysis. Journal of Management Studies 56(1): 19-56.

Hatak I and Snellman K (2017) The influence of anticipated regret on business start-up behaviour. International Small Business Journal 35(3): 349-360.

$\mathrm{He} \mathrm{H}$ and Brown AD (2013) Organizational identity and organisational identification: a review of the literature and suggestions for future research. Group and Organization Management 38(1): 3-35.

Invernizzi AC, Menozzi A, Passarani DA, et al. (2016) Entrepreneurial overconfidence and its impact upon performance. International Small Business Journal 35(6): 709-728.

Isabella LA (1990) Evolving interpretations as a change unfolds: how managers construe key organizational events. Academy of Management Journal 33(1): 7-41.

Islam G and Keliher M (2018) Leading through ritual: ceremony and emperorship in early modern China. Leadership 14(4): 435-459.

Islam G and Zyphur MJ (2009) Rituals in organizations. Group and Organization Management 34(1): $114-139$.

Jenkins A and McKelvie A (2017) Is this the end? Investigating firm and individual level outcomes post-failure. Journal of Business Venturing Insights 8: 138-143.

Jenkins A and McKelvie A (2016) What is entrepreneurial failure? Implications for future research. International Small Business Journal 34(2): 176-188.

Johns G (2006) The essential impact of context on organizational behavior. Academy of Management Review 31(2): 386-408.

Johnson G, Prashantham S, Floyd SW, et al. (2010) The ritualization of strategy workshops. Organization Studies 31(12): 1589-1618.

Katila R, Chen EL and Piezunka H (2012) All the right moves: how entrepreneurial firms compete effectively. Strategic Entrepreneurship Journal 6: 116-132.

Kulkarni M (2020) Rituals and institutional maintenance: the case of the beating retreat ceremony. Journal of Management Inquiry 29(2): 159-173.

Maitlis S and Christianson MK (2014) Sensemaking in organizations: taking stock and moving forward. Academy of Management Annals 8(1): 57-125.

Mandl C, Berger ESC and Kuckertz A (2016) Do you plead guilty? Exploring entrepreneurs' sensemakingbehavior link after business failure. Journal of Business Venturing Insights 5: 9-13.

Mantere S, Aula P, Schildt H, et al. (2013) Narrative attributions of entrepreneurial failure. Journal of Business Venturing 28(4): 459-473.

Marchiori D and Warglien M (2008) Predicting human interactive learning by regret-driven neural networks. Science 319(5866): 1111-1113.

Mazmanian M and Beckman CM (2018) "Making” your numbers: engendering organizational control through a ritual of quantification. Organization Science 29(3): 357-379.

McCarthy AM, Schoorman DF and Cooper AC (1993) Reinvestment decisions by entrepreneurs: Rational decision-making or escalation of commitment? Journal of Business Venturing 8: 9-24.

McCracken G (1988) The Long Interview: Qualitative Research Series 13. London, UK: Sage Publications Ltd.

McMullen JS and Shepherd DA (2006) Entrepreneurial action and the role of uncertainty in the theory of the entrepreneur. Academy of Management Review 31(1): 132-152.

Meschi PX and Métais E (2015) Too big to learn: the effects of major acquisition failures on subsequent acquisition divestment. British Journal of Management 26(3): 408-423. 
Milliken FJ (1987) Three types of perceived uncertainty about the environment: state, effect, and response uncertainty. Academy of Management Review 12(1): 133-143.

Mills C (2010) Experiencing gossip: the foundations for a theory of embedded organizational gossip. Group \& Organization Management 35(2): 213-240.

Morris MH, Neumeyer X, Jang Y, et al. (2018) Distinguishing types of entrepreneurial ventures: an identitybased perspective. Journal of Small Business Management 56(3): 453-474.

Navis C and Glynn MA (2010) How new market categories emerge: temporal dynamics of legitimacy, identity, and entrepreneurship in satellite radio, 1990-2005. Administrative Science Quarterly 55: 439-471.

Packard MD, Clark BB and Klein PG (2017) Uncertainty types and transitions in the entrepreneurial process. Organization Science 28(5): 781-964.

Peterson MF (1998) Embedded organizational events: the units of process in organization science. Organization Science 9(1): 16-33.

Peterson MF and Smith PB (2000) Sources of meaning, organization and culture: making sense of organizational events. In: Ashkanasy N, Wilderom C and Peterson MF (eds), Handbook of Organizational Culture and Climate. Thousand Oaks, CA: Sage Press, pp. 101-115.

Radu-Lefebvre M and Randerson K (2020) Successfully navigating the paradox of control and autonomy in succession: the role of managing ambivalent emotions. International Small Business Journal 38(3): 184-210.

Rauch A, Fink M and Hatak I (2018) Stress processes: an essential ingredient in the entrepreneurial process. Academy of Management Perspectives 32(3): 340-357.

Rogoff EG, Lee MS and Suh DC (2004) "Who done it?" Attributions by entrepreneurs and experts of the factors that cause and impede small business success. Journal of Small Business Management 42(4): 364-376.

Rosen M (1988) You asked for it: christmas at the bosses' expense. Journal of Management Studies 11: 31-48.

Sarasvathy S (2001) Causation and effectuation: toward a theoretical shift from economic inevitability to entrepreneurial contingency. Academy of Management Review 26(2): 243-263.

Sing S, Doyle Corner, P and Pavlovich K (2015) Failed, not finished: a narrative approach to understanding venture failure stigmatization. Journal of Business Venturing 30(1): 150-166.

Spicer A (2020) Organizational culture and COVID-19. Journal of Management Studies 57(8): 1737-1740.

Shane S and Venkataraman S (2000) The promise of entrepreneurship as a field of research. Academy of Management Review 25(1): 217-226.

Shepherd DA (2009) Grief recovery from the loss of a family business: a multi- and meso-level theory. Journal of Business Venturing 24(1): 81-97.

Shepherd DA, Williams TA, Patzelt H (2015) Thinking about entrepreneurial decision making: review and research agenda. Journal of Management 41(1): 11-46.

Simon D (2004) A third view of the black box: cognitive coherence in legal decision making. The University of Chicago Law Review 71(2): 511-586.

Sirmon DG, Hitt MA and Ireland RD (2007) Managing firm resources in dynamic environments to create value: looking inside the black box. The Academy of Management Journal 32(2): 273-292.

Smith ACT and Stewart B (2011) Organizational rituals: features, functions and mechanisms. International Journal of Management Reviews 13: 113-133.

Smith JR, Hogg MA, Martin R, et al. (2007) Uncertainty and the influence of group norms in the attitudebehaviour relationship. The British Journal of Social Psychology 46: 769-792.

Snihur Y (2016) Developing optimal distinctiveness: organizational identity processes in new ventures engaged in business model innovation. Entrepreneurship \& Regional Development 28(3-4): 259-285. 
Spiggle S (1994) Analysis and interpretation of qualitative data in consumer research. Journal of Consumer Research 21(3): 491-504.

Statistics of US Businesses (2018). Accessed here https://sbecouncil.org/about-us/facts-and-data/.

Stevenson HH and Jarillo JC (1990) A paradigm of entrepreneurship: entrepreneurial management. Strategic Management Journal 11(5): 17-27.

Stinchcombe AL (1965) Social structure and organizations. In: March JG (ed), Handbook of Organizations. Chicago: Rand McNally \& Company, pp. 142-193.

Strauss A and Corbin J (1990) Basics of Qualitative Research Techniques and Procedures for Developing Grounded Theory. Thousand Oaks, California: Sage Publications Ltd.

Townsend DM, Hunt RA, McMullen JS, et al. (2018) Uncertainty, knowledge problems, and entrepreneurial action. Academy of Management Annals 12(2): 659-687.

Trice HM and Beyer JM (1984) Studying Organizational Cultures Through Rites and Ceremonials. Academy of Management Review 9(4): 653-669.

Turner V (1969) The Ritual Process. New York: Aldine de Gruyter.

Ucbasaran D, Shepherd DA, Lockett A, et al. (2013) Life after business failure. Journal of Management 39(1): 163-202.

Van den Ende L and van Marrewijk A (2018) The point of no return: ritual performance and strategy making in project organizations. Long Range Planning 51(3): 451-462.

Walsh G and Cunningham J (2016) Business failure and entrepreneurship: emergence, evolution and future research. Foundations and Trends in Entrepreneurship 12(3): 163-285.

Walsh G and Cunningham J (2017) Regenerative failure and attribution: examining the underlying processes affecting learning. International Journal of Entrepreneurial Behavior \& Research 23(4): 688-707.

Weick KE (1995) Sensemaking in Organizations. Thousand Oaks, California: Sage Publications Ltd.

Wolfe MT and Shepherd DA (2015a) "Bouncing back" from a loss: entrepreneurial orientation, emotions, and failure narratives. Entrepreneurship Theory and Practice 39(3): 675-700.

Wolfe MT and Shepherd DA (2015b) What do you have to say about that? Performance events and narratives' positive and negative emotional content. Entrepreneurship Theory and Practice 39(4): 409-421.

Yamakawa Y, Peng MW and Deeds DL (2015) Rising from the ashes: cognitive determinants of venture growth after entrepreneurial failure. Entrepreneurship Theory and Practice 39(2): 209-236.

Yang T and Aldrich HE (2017) "The liability of newness" revisited: theoretical restatement and empirical testing in emergent organizations. Social Science Research 63: 36-53.

Zacharakis AL, Meyer GD and DeCastro J (1999) Differing perceptions of new venture failure: a matched exploratory study of venture capitalists and entrepreneurs. Journal of Small Business Management 37(3): $1-14$.

Zhang SX and Cueto J (2017) The study of bias in entrepreneurship. Entrepreneurship Theory and Practice 41(3): 419-454.

\section{Author biographies}

David Johnson is a Lecturer (Assistant Professor) in Entrepreneurship at the Adam Smith Business School, University of Glasgow. Broadly speaking, David studies the relationship between uncertainty and entrepreneurial cognition, entrepreneurial behaviour, and venturing. More specifically, his research explores university-centred entrepreneurial ecosystems, technology transfer, academic entrepreneurs, and life science commercialisation.

Adam J Bock is a Lecturer in Entrepreneurship at University of Wisconsin. He is an award-winning academic, serial entrepreneur, financier, executive education facilitator and executive coach. He is the co-author of three books and more than a dozen peer-reviewed research articles on 
entrepreneurship, innovation, and business models. He co-founded and served as executive management of four biotechnology ventures and actively mentors entrepreneurs and executives around the world.

Alexander Thompson is a Senior Lecturer at the University of Exeter. His research interests include small firm entrepreneurship, ethnographic research and socio-cultural approaches to marketing. He has published in the Journal of Business Research, Journal of Marketing Management, Journal of Professions and Organization, and The Routledge Companion to Visual Organization. 